\title{
Language learner beliefs and study abroad: A study on English as a lingua franca (ELF)
}

\author{
Eda Kaypak ${ }^{\mathrm{a}}$, Deniz Ortaçtepe ${ }^{\mathrm{b}, *}$ \\ ${ }^{a}$ School of Foreign Languages, Anadolu University, Eskişehir, Turkey \\ ${ }^{\mathrm{b}}$ MA TEFL Program, Bilkent University, Ankara, Turkey
}

\section{A R T I C L E I N F O}

\section{Article history:}

Received 11 March 2013

Received in revised form 2 January 2014

Accepted 8 January 2014

\section{Keywords:}

English as a Lingua Franca (ELF)

ELF communities

Study abroad

Language learner beliefs

\begin{abstract}
A B S T R A C T
The English language used to be specific to English-speaking countries such as the U.S.; however, it has evolved to become the new lingua franca all around the world. Considering the growing number of students studying abroad in English as a lingua franca (ELF) communities, the present study aimed to investigate the relationship between Turkish exchange students' beliefs about English language learning and their study abroad sojourns in ELF contexts. The data were collected mainly through three instruments: language learner belief questionnaire (LLBQ), elicited journals, and a study abroad perception questionnaire (SAPQ). The quantitative and qualitative results revealed three important findings. First, there is a bi-directional relationship between students' pre- and post-beliefs about English language learning and their perceptions of study abroad experiences. Second, Turkish exchange students' overall beliefs remained almost the same across pre- and post-study abroad, suggesting that students might need stays longer than five months to have any observable changes in their beliefs about language learning. Third, although the current study's participants reported a commitment toward native-speaker norms, they shifted their focus from accuracy to intelligibility, which helped them achieve their ultimate goal, that is, successful interaction in ELF communities.
\end{abstract}

(c) 2014 Elsevier Ltd. All rights reserved.

\section{Introduction}

The nature of language learners' beliefs has been one of the most controversial topics in the field of English language teaching (ELT). Some researchers have perceived them as part of the stable metacognitive knowledge (e.g., Sakui \& Gaies, 1999; Wenden, 1998, 1999), while others have claimed that they are context-sensitive, thus dynamic and lively (e.g., Amuzie \& Winke, 2009; Lee, 2007; Tanaka \& Ellis, 2003). Despite these opposing views, there is consensus on the role of learner beliefs in study abroad contexts, since these beliefs about language learning are related to learners' "expectation of, commitment to, success in, and satisfaction with" their study abroad experience (Horwitz, 1988, p. 283). Several studies examined the effects of study abroad on learner beliefs in second language (L2) contexts such as the U.S. or the U.K. (e.g., Amuzie \& Winke, 2009; Tanaka \& Ellis, 2003; Yang \& Kim, 2011). Yet, English is no longer specific to these English-speaking countries since it is used all around the world as the new lingua franca. Especially in Europe, English is typically the most commonly studied language during the K-12 years (Eurostats News Release, 2013). The report published by the European Commission's division of statistics revealed that $94 \%$ of the secondary students and $83 \%$ of the primary school students are

\footnotetext{
* Corresponding author. Tel.: +90 5546700475.

E-mail addresses: ekaypak@anadolu.edu.tr (E. Kaypak), deniz.ortactepe@bilkent.edu.tr (D. Ortaçtepe).
} 
learning English as their first foreign language (Eurostats News Release, 2013). Given the growing number of students studying abroad in ELF communities in the European Union (Kinginger, 2009; Turkish National Agency, 2011), particularly through mobility programs such as Erasmus, Comenius and Leonardo, a closer look into the use of English in these English as a lingua franca (ELF) communities is needed. Hence, this exploratory study aims to investigate the relationship between these two current issues; language learners' beliefs and their study abroad experiences in ELF communities.

\section{Literature review}

\subsection{English as a lingua franca (ELF) and study abroad}

Although English as a lingua franca (ELF) has been defined in various ways by different researchers (e.g., Elder \& Davies, 2006; Firth, 1996; Jenkins, 2006, 2007, 2009; Mauranen, Perez-Llantada, \& Swales, 2010; Seidlhofer, 2005), the most agreed definition is that "it is a 'contact language' between persons who share neither a common native tongue nor a common (national) culture, and for whom English is the chosen foreign language of communication” (Firth, 1996, p. 240).

As the new lingua franca, English has gained many responsibilities, one of which is acting as a common language for interaction among study abroad students. The historical roots of study abroad research date back to the 1960 s and 1970 s during which Carroll's (1967) and Schumann and Schumann's (1977) work emerged as the pioneering examinations of the role of study abroad on language development. Following these two seminal papers, many studies were conducted on how study abroad influences language learning in terms of proficiency (e.g., Allen \& Herron, 2003; Freed, 1990; Magnan, 1986), fluency (e.g., Segalowitz \& Freed, 2004; Wood, 2007), reading and writing (e.g., Dewey, 2004; Kinginger, 2008; Sasaki, 2004, 2007), grammatical competence (e.g., DeKeyser, 1991; Howard, 2005) and the use of speech acts (e.g., Matsumura, 2001; Shardakova, 2005). Studies have also been conducted on the communicative features of the study abroad contexts (e.g., Kline, 1998; Levin, 2001; Mathews, 2001), and the influence of study abroad on language socialization and identity (e.g., Hashimoto, 1993; Kinginger, 2008; Murphy-Lejeune, 2002; Ortaçtepe, 2012).

All these studies have been carried out in different study abroad contexts such as the U.S., the U.K., Canada, France, Hungary, Germany, Japan, China, Thailand, Australia, and many more. The following sub-sections will present previous research conducted in ESL and ELF study abroad contexts so as to highlight the differences between them as well as to draw attention to the significance of the social environment in which the English language is used.

\subsubsection{Study abroad in English as a second language (ESL) contexts}

The last two decades have witnessed several case studies conducted on study abroad in ESL contexts (e.g., Matsumura, 2001; Ortaçtepe, 2013; Sasaki, 2004, 2007; Serrano, Llanes, \& Tragant, 2011; Tanaka, 2007). These studies indicated that study abroad in different ESL contexts, which use English as their first language, has an active, but partial role in students' foreign language development. As Tanaka (2007) stated in a qualitative study with 29 Japanese language learners studying in New Zealand for 12 weeks, study abroad in ESL contexts does not necessarily guarantee opportunities to use the target language inside and outside the classroom. Therefore, the more contact students have with the target language during their study abroad sojourns, the more improvement they will demonstrate in their L2 (Bardovi-Harlig \& Bastos, 2011; Barron, 2003; Sasaki, 2011).

\subsubsection{Study abroad in English as a lingua franca (ELF) contexts}

Recently, with the increasing popularity of the ELF notion, there has been a shift from study abroad in ESL contexts to ELF contexts. A study undertaken by Baker (2009) to examine the language-culture relationship for a group of English language users in a Thai university is a good illustration of this interest. His findings highlighted that the participants needed the ability to negotiate, mediate, and be creative in their use and interpretation of English rather than focusing on the knowledge of the target language cultures (e.g., British and/or American). In a different study, Virkkula and Nikula (2010) concluded that study abroad in an ELF context had a remarkable impact on students' identity construction as English language users.

The research into study abroad in ELF contexts has also gained popularity with the emergence of student mobility programs in Europe such as Erasmus (European community action scheme for the mobility of university students). Kalocsai (2009), in her study with 70 Erasmus students studying in Hungary and the Czech Republic, examined how those exchange students, whose common language was only English, were socialized into their new communities of practice. The qualitative data collected via interviews revealed that in these ELF communities, exchange students developed a new repertoire of shared ways of speaking. In other words, they realized that they did not need to adjust their language on the basis of some external norm but instead they invented new forms, borrowed from other languages, and/or maintained their own accents to effectively negotiate meaning and to establish interpersonal relationships. As a result, the researcher suggested that more research be conducted on Erasmus students and the communities of practice they visit.

The current studies that delved into the nature of ESL and ELF communities indicate that an ELF context has its own unique characteristics in terms of the history of contact with English, the use of English, the goals for English learners, and the range of users across different social groups (Berns, 2009), all of which distinguish it from an ESL context in which English is used primarily to communicate with native speakers. More specifically, in ESL contexts, variations in language are considered errors since ESL communication depends on native-speaker norms (Jenkins, 2006). On the other hand, the speakers in ELF 
contexts are more tolerant to variations in pronunciation, wording, and grammar (Jenkins, 2006) since they use the language as a tool for interpersonal communication without relying on shared sociocultural values and linguistic norms (Berns, 2009).

\subsection{English language and learner beliefs}

Learner beliefs were first considered as part of the metacognitive aspects of language learning within the realm of cognitive psychology (e.g., Alexander \& Dochy, 1995; Horwitz, 1999; Wenden, 1998, 1999). However, the rise of sociocultural theory led researchers to conceptualize learner beliefs as "contextually situated social meaning emerging in specific sense-making activities" (Negueruela \& Azarola, 2011, p. 368). Many studies from a sociocultural perspective have been conducted on learner beliefs and their role in study abroad contexts (e.g., Amuzie \& Winke, 2009; Lee, 2007; Tanaka \& Ellis, 2003; Yang \& Kim, 2011). In their study, Tanaka and Ellis (2003) focused on the role of a study abroad program in the U.S. on 166 Japanese students' beliefs about language learning and their English proficiency. The results showed statistically significant changes in students' beliefs in analytic language learning, experiential language learning and self-efficacy/confidence after 15 weeks of study abroad. Similarly, in his dissertation investigating the effects of study abroad on language learner beliefs, Lee (2007) suggested that learners at the early stages of study abroad showed significant changes in their beliefs about the importance of grammar and the challenges of language learning. These ESL-based studies agreed on the dynamic interplay among beliefs, behaviors, and learning outcomes in the sense that the L2 learning environment leads to not only the modification of learners' existing beliefs but also the formation of new ones (Tanaka \& Ellis, 2003). Notwithstanding, how ELF contexts may affect language learner beliefs still remains unexplored. In this respect, the present study addressed the following research questions:

1 What changes occurred in Turkish exchange students' beliefs about English language learning after studying abroad for a semester in ELF communities?

2 What relationship is there between these students' beliefs about English language learning and their perceptions of study abroad in ELF communities?

3 How can these students' beliefs about English language learning and their perceptions of study abroad be explained by their stories of study abroad experiences in ELF communities?

Throughout the present study, the term English language learning is used as an umbrella term to refer to the participants' use of English in various contexts and for various purposes as well as their conscious and/or subconscious learning experiences throughout their stay in ELF communities.

\section{Method}

\subsection{Participants}

The participants of the current study were 53 Turkish Erasmus exchange students who intended to study in different ELF communities during the 2011-2012 Spring semester. The students who were studying at a large Turkish state university were chosen as the sample of the present study, since they were highly diverse in terms of their majors, previous experiences abroad, years of English language learning, and the ELF communities in which they would study for almost five months (see Table 1).

\subsection{Instruments}

In the present study, the data were collected by means of three instruments: a language learner belief questionnaire (LLBQ), elicited journals, and a study abroad perception questionnaire (SAPQ). The LLBQ was a 5-point Likert scale including two major sections on demographic information and learner beliefs (see Appendix 1). The first section consisted of nine items that aimed to shed light on the background of the participants. The second section, learner beliefs, included 29 items aiming to investigate the participants' beliefs about English language learning on the basis of four sub-categories: a) self-efficacy, b) learner autonomy, c) learner attitudes toward the role of English in the globe, and d) learner attitudes toward learning English. The second part of LLBQ was developed by combining items from various questionnaires examining language learner beliefs and attitudes (Amuzie \& Winke, 2009; Cotterall, 1999; He \& Li, 2009; Horwitz, 1985; Kobayashi, 2002; Pan \& Block, 2011; Zhang \& Cui, 2010). Several of the items remained intact while others were adapted to align them with the purpose of the study. In order to check its reliability, the questionnaire was piloted with 11 undergraduate students from different departments at a Turkish university and the analysis indicated that the questionnaire as a whole had strong internal consistency $(\alpha=.86)$. The pilot group was also asked to make comments on the questionnaire to see whether there were any unclear, ambiguous items. In line with the reliability analysis as well as the comments provided, necessary adaptations were made and the final version of the LLBQ was developed to serve as a pre-study abroad learner belief questionnaire (pre-belief questionnaire) to be conducted at the beginning of the research and a post-study abroad learner belief questionnaire (postbelief questionnaire) to be administered at the end of the research.

The current study also employed ongoing, elicited journals, which have been widely used in the literature during the past decade (e.g., Kinginger, 2008; Norton, 2000; Tanaka, 2007; Yang \& Kim, 2011). Depending on their scores on the pre-belief 
Table 1

\begin{tabular}{|c|c|c|}
\hline Background Information & $N$ & $\%$ \\
\hline \multicolumn{3}{|l|}{ Faculty } \\
\hline Faculty of Education & 6 & 11.3 \\
\hline Faculty of Science & 8 & 15.1 \\
\hline Faculty of Fine Arts & 5 & 9.4 \\
\hline Faculty of Economics and Administrative Sciences & 9 & 17 \\
\hline Faculty of Communication Sciences & 5 & 9.4 \\
\hline Faculty of Engineering and Architecture & 11 & 20.8 \\
\hline Other & 9 & 17 \\
\hline \multicolumn{3}{|l|}{ Age } \\
\hline $20-22$ & 45 & 84.9 \\
\hline $23-25$ & 6 & 11.3 \\
\hline $26+$ & 2 & 3.8 \\
\hline \multicolumn{3}{|l|}{ Gender } \\
\hline Female & 34 & 64.2 \\
\hline Male & 19 & 35.8 \\
\hline \multicolumn{3}{|l|}{ English language learning experience } \\
\hline $1-4$ & 8 & 15.1 \\
\hline $5-8$ & 17 & 32.1 \\
\hline $9-12$ & 17 & 32.1 \\
\hline $13+$ & 11 & 20.7 \\
\hline \multicolumn{3}{|l|}{ Abroad experience } \\
\hline Yes & 13 & 24.5 \\
\hline No & 40 & 75.5 \\
\hline \multicolumn{3}{|l|}{ ELF communities visited through Erasmus } \\
\hline Germany & 5 & 9.4 \\
\hline Holland & 4 & 7.5 \\
\hline Spain & 5 & 9.4 \\
\hline Italy & 5 & 9.4 \\
\hline Poland & 19 & 35.8 \\
\hline Slovenia & 3 & 5.7 \\
\hline Austria & 3 & 5.7 \\
\hline Czech Republic & 3 & 5.7 \\
\hline Other & 6 & 11.4 \\
\hline
\end{tabular}

Note. This table reflects demographic information about the participants and settings of the study that are collected via pre-belief questionnaires before students went abroad through Erasmus exchange program.

questionnaire, 12 volunteers were asked to describe their study abroad experiences in ELF communities. Half of these 12 volunteers had extremely positive beliefs about English language learning while the other half had neutral ${ }^{1}$ beliefs. In these journal entries, the participants were asked to share their experiences abroad by giving examples from; a) their academic life, b) social life, and c) English language use. However, only five of these students (four with extremely positive beliefs and one with neutral beliefs about English language learning) completed all four journals (four journals per student, 20 journals in total) and became the participants of the qualitative part of the present study.

The last data collection instrument (SAPQ) was a 15-item 5-point Likert scale aiming to explore the participants' perceptions about their study abroad experiences (see Appendix 2). The SAPQ was designed by combining items from different study abroad perception questionnaires (Albers-Miller, Prenshaw, \& Straughan, 1999; Deci, Eghrari, Patrick, \& Leone, 1994; Jones \& Cunningham, 2008; Kasapoglu-Önder \& Balc1, 2010; Lee, 2009; Ryan, 1982). To check its reliability, the perception questionnaire was administered to 20 undergraduate students from different Turkish state universities, who had studied in various ELF communities before through the Erasmus exchange program. The Cronbach's alpha coefficient of the whole questionnaire was calculated as .89, indicating strong reliability (Huck, 2004). The pilot group was also asked to make comments on the questionnaire, and adjustments were made accordingly.

\subsection{Procedure}

The first data collection via the pre-belief questionnaire was carried out at the end of the 2011-2012 fall semester just before the participants went abroad. The participants were recruited in an Erasmus orientation meeting held in December 17, 2011, two months before they began studying abroad. They were first asked to fill in the LLBQ which also included a consent form. On the third week of February, the first elicited journal questions were e-mailed to the participants. The data collection via monthly elicited journals lasted until June 2012, the month in which the participants began to return to Turkey. In the first week of June, the post-belief questionnaire and the study abroad perception questionnaire were sent to all participants via Google documents. ${ }^{2}$

\footnotetext{
${ }^{1}$ None of the participants reported negative beliefs about English language learning in the pre-belief questionnaire.

2 The participants were reached via Google documents since some of them were still abroad while others had already come back to Turkey.
} 


\subsection{Data analysis}

The data collected via the questionnaires and elicited journals were analyzed quantitatively and qualitatively, respectively. In order to see whether the data met the assumptions of a parametric test, the Shapiro-Wilk test was used since it is found to be more powerful when compared to the other tests of normality (Razali \& Wah, 2011). The results indicated that only the data coming from the perception questionnaire $(S-W=.958 \mathrm{df}=53, p=.060$ ) were normally distributed. Although the Shapiro-Wilk test indicated a non-normal distribution for pre- and post-beliefs, the skewness and kurtosis values for these two data sets were between -1 and +1 , evidencing a unimodal and symmetrical distribution, thus enabling parametric tests to be run (Thompson, 2008).

First, in order to identify whether there was a change in the Erasmus exchange students' beliefs about English language learning pre- and post-study abroad, the questionnaire data were analyzed in SPSS 18 by means of a pairedsamples $t$-test, which is used to compare the mean scores from the same students at two different times (Hatch \& Lazaraton, 1991). Second, in order to see the extent to which the participants' pre- and post-beliefs were related to their perceptions of study abroad, a Pearson product-moment correlation analysis was conducted with the mean scores from the study abroad perception, pre- and post-belief questionnaires since this test allows establishing the strength of relationships among continuous variables (Hatch \& Lazaraton, 1991). Third, the data from the elicited journals were evaluated thematically in order to provide insights into the participants' beliefs about English language learning and their study abroad sojourns in ELF communities. Thematic analysis was conducted to analyze the data from the ongoing, elicited journals, for this form of analysis enables the identification of recurring motifs notable in the participants' stories (Strauss \& Corbin, 1990).

\section{Results}

\subsection{Language learner beliefs across pre- and post-study abroad}

A paired-samples $t$-test was conducted in order to examine if there was a change in the participants' beliefs about English language learning across pre- and post-study abroad.

Table 2

Language learner beliefs about English language learning across pre- and post-study abroad.

\begin{tabular}{|c|c|c|c|c|c|}
\hline \multirow[t]{2}{*}{ Questionnaires } & \multirow[t]{2}{*}{$M$} & \multirow[t]{2}{*}{ SD } & \multicolumn{3}{|c|}{$t$-test } \\
\hline & & & $\mathrm{df}$ & $t$ & $p$ \\
\hline Pre-belief & 4.07 & .33 & 52 & -1.558 & .13 \\
\hline Post-belief & 4.13 & .31 & & & \\
\hline
\end{tabular}

As shown in Table 2, the difference between the overall mean scores of pre- and post-belief questionnaires was low ( $M$ pre-belief $=4.07, M$ post-belief = 4.13); that is, even though the participants' post-belief scores were a little higher than their pre-belief scores, the difference was not statistically significant. A follow-up paired-samples $t$-test was run on the specific items in the pre- and post-belief questionnaires with the purpose of exploring those belief statements with the most change across pre- and post-study abroad.

Table 3

Belief statements showing the most change.

\begin{tabular}{|c|c|c|c|c|c|}
\hline \multirow[t]{2}{*}{ Questionnaire Items } & \multirow[t]{2}{*}{$M$} & \multirow[t]{2}{*}{ SD } & \multicolumn{3}{|c|}{$t$-test } \\
\hline & & & df & $t$ & $p$ \\
\hline \multirow[t]{2}{*}{ 10. I am afraid of making mistakes when speaking to other people. ${ }^{a}$ (Pre-Post) } & 3.31 & 1.12 & 50 & 2.782 & $.01^{* *}$ \\
\hline & 2.53 & 1.19 & & & \\
\hline \multirow[t]{2}{*}{ 17. It is important to repeat and practice English. (Pre-Post) } & 4.62 & .53 & 52 & -2.060 & $.04 *$ \\
\hline & 4.77 & .42 & & & \\
\hline \multirow[t]{2}{*}{ 19. English will still be important in the world in the future (upcoming years). (Pre-Post) } & 4.04 & .84 & 51 & -2.085 & $.04 *$ \\
\hline & 4.31 & .73 & & & \\
\hline \multirow[t]{2}{*}{ 26. I can make friends from different countries by using English. (Pre-Post) } & 4.49 & .50 & 52 & -3.238 & $.00 * *$ \\
\hline & 4.74 & .45 & & & \\
\hline \multirow[t]{2}{*}{ 29. It is necessary to know British or American culture to speak English well. ${ }^{b}$ (Pre-Post) } & 2.91 & 1.10 & 52 & -2.454 & $.02 *$ \\
\hline & 3.32 & 1.14 & & & \\
\hline
\end{tabular}

${ }^{*} p<.05, * * p<.01$.

a Item 10 is a reverse item, so the results were interpreted accordingly.

b Item 29 is a reverse item, so the results were interpreted accordingly. 
As Table 3 indicates, the differences between the items focusing on Turkish exchange students' beliefs about the issues of making mistakes in English (item\# 10), practicing English (item\# 17), the importance of English around the world (item\# 19), making friends from other countries with the help of English (item\# 26), and knowledge about the cultures of Englishspeaking countries (item\# 29) were statistically significant ( $p=.01 ; p=.04 ; p=.04 ; p=.00 ; p=.02$ ). Right after the study abroad period, Turkish students reported that they; a) were more afraid of making mistakes while talking to others in English, b) realized more the importance of practice in learning English, c) recognized more the global role of English, d) considered English as an aid to make friends from different countries, and e) needed less the cultural knowledge of the English-speaking countries (e.g., the U.S., the U.K. and Australia) to speak English well.

\subsection{The relationship between students' beliefs about English language learning and their perceptions of study abroad experiences}

The descriptive statistics revealed that the participants' perceptions about their study abroad experiences in ELF contexts were fairly positive $\left(M=4.35^{3}\right)$. Pearson product-moment correlation coefficients were also computed to determine the extent of the relationship between their perceptions of study abroad experiences and pre- and post-beliefs.

Table 4

Relationship between students' pre- and post-beliefs and their perceptions of study abroad experiences.

\begin{tabular}{lll}
\hline & Pre-Belief & Post-Belief Study \\
\hline Pre-Belief & - & \\
Post-Belief & $.623^{* *}$ & - \\
Study Abroad Perception & $.363^{* *}$ & $.499^{* *}$ \\
\hline
\end{tabular}

$* * p<.01$ level.

Table 4 shows that Turkish students' perceptions of study abroad experiences were strongly correlated with their pre$\left(r(51)=.363, p<.01, R^{2}=.132\right)$ and post-beliefs $\left(r(51)=.499, p<.01, R^{2}=.249\right)$. That is, Turkish exchange students' perceptions of study abroad experiences were related not only to their post-beliefs about English language learning shaped through their study abroad sojourns but also to the beliefs they held prior to study abroad. Yet, the correlation between the participants' post-beliefs and their study abroad perceptions was relatively stronger than their pre-beliefs, as also evidenced by the effect size for pre- and post-beliefs being .132 and .249 , respectively.

As a second step, a partial correlation analysis was conducted in order to statistically remove the overlap between the preand post-beliefs and to evaluate more closely the relationship between students' post-beliefs and study abroad perceptions. Holding students' pre-beliefs constant, the results again revealed a significant relationship between post-beliefs and study abroad perceptions $(r(50)=.375, p<.05)$. These findings confirm that there was a stronger relationship between the participants' post-beliefs and their perceptions of study abroad in comparison to their pre-beliefs, a finding that will be explained with their journals (See Section 4.3).

As mentioned earlier, in the present study, students' overall beliefs about English language learning are considered as a combination of several variables; therefore, another Pearson product-moment correlation analysis was conducted in order to examine the relationship between students' perceptions of study abroad experiences and their pre- and post-beliefs in regard to self-efficacy, learner autonomy, the role of English in the world, and learning English in general.

Table 5

Relationship between students' perceptions of study abroad experiences and their pre- and post-beliefs on the basis of four variables; self-efficacy, learner autonomy, the role of English in the world, and learning English.

\begin{tabular}{|c|c|c|c|c|c|c|c|c|c|}
\hline & 1 & 2 & 3 & 4 & 5 & 6 & 7 & 8 & 9 \\
\hline 1. Study Abroad Perception & - & & & & & & & & \\
\hline 2. Self-Efficacy (Pre) & .146 & - & & & & & & & \\
\hline 3. Self-Efficacy (Post) & .265 & $.325^{*}$ & - & & & & & & \\
\hline 4. Learner Autonomy (Pre) & $.385^{* *}$ & $.349 *$ & $.281^{*}$ & - & & & & & \\
\hline 5. Learner Autonomy (Post) & $.598 * *$ & .133 & $.463 * *$ & $.488^{* *}$ & - & & & & \\
\hline 6. The Role of English (Pre) & .238 & $.392^{* *}$ & .207 & $.384 * *$ & $.280^{*}$ & - & & & \\
\hline 7. The Role of English (Post) & .249 & .159 & $.329 *$ & $.293^{*}$ & $.481^{* *}$ & $.484^{* *}$ & - & & \\
\hline 8. Learning English (Pre) & $.402 * *$ & $.507^{* *}$ & $.530 * *$ & $.555^{* *}$ & $.379 * *$ & $.585^{* *}$ & $.237^{*}$ & - & \\
\hline 9. Learning English (Post) & $.486^{* *}$ & $.343^{*}$ & $.650 * *$ & $.413^{* *}$ & $.457 * *$ & $.340^{*}$ & $.299 *$ & $.754^{* *}$ & - \\
\hline
\end{tabular}

$* * p<.01$ level., ${ }^{*} p<.05$ level.

According to the Pearson product-moment correlation coefficients presented in Table 5, the Turkish students' perceptions of study abroad experiences were significantly related to their pre-beliefs about learner autonomy $(r(51)=.385$,

${ }^{3} M<2.33=$ negative, $M>3.68=$ positive, $M$ between 2.34 and $3.67=$ neutral. 
$p<.01)$ and learning English $(r(51)=.402, p<.01)$. Not surprisingly, this significant relationship persisted between their perceptions of study abroad experiences and their post-beliefs about learner autonomy $(r(51)=.598, p<.01)$ and learning English $(r(51)=.486, p<.01)$. On the other hand, the results revealed that students' perceptions of study abroad experiences were not statistically related to their pre- and post-beliefs in terms of self-efficacy and the role of English in the world, a finding that may have resulted from the diversity of ELF contexts the participants studied in (see Section 4.3.3.).

\subsection{Qualitative analysis of the change in Turkish students' language beliefs through their study abroad experiences}

The qualitative data from the elicited journals of the five students were analyzed to gain deeper insights into the participants' beliefs about English language learning and their experiences of study abroad (see Table 6 for more information about the diarists).

Table 6

General characteristics of the diarists.

\begin{tabular}{|c|c|c|c|c|c|}
\hline & P1 & P2 & P3 & P4 & P5 \\
\hline Gender & Female & Female & Female & Male & Female \\
\hline Department & I.D. & T.H.M. & T.H.M. & C. & I.D. \\
\hline English language learning experience & $5-8$ & $9-12$ & $5-8$ & $5-8$ & $1-4$ \\
\hline ELF community visited through Erasmus & Slovenia & Poland & Austria & Holland & Poland \\
\hline
\end{tabular}

Note. This table reflects information about the general characteristics of the participants who volunteered to keep elicited journals. In Table 6, P represents participant. In the department column, I.D. represents Industrial Design; T.H.M. represents Tourism and Hotel Management; and C. represents Communication. In the English language learning experience column, the numbers were provided according to the number of years the participants have been learning English.

According to the thematic analysis, Turkish exchange students' beliefs about English language learning were found to be influenced by three different factors: a) noticing the differences between ELF and ESL interactions and its effects on selfefficacy, b) discovering the role of learner autonomy in language learning, and c) re-conceptualizing the fluency/accuracy distinction depending on the visited ELF community.

\subsubsection{Noticing the differences between ELF and ESL interactions and its effects on self-efficacy}

Three of the diarists stated that they felt insecure while using English at the beginning of their study abroad sojourns since they felt less competent in English than their European contemporaries:

Participant 3: Some of my friends coming from the other European countries speak English as their native language. I feel like I am using the same phrases and same structures all the time. (Journal 1)

Participant 4: Among all those coming from Europe, the worst ones are the Turkish and Spanish in terms of English. Naturally, I lose my self-confidence a little bit while communicating with people who speak English very well. (Journal 1)

These excerpts confirm the predictions of Turkish National Agency (2011) in terms of how Turkish Erasmus students might face difficulties in their academic and social lives due to a lack of proficiency in the English language. Nevertheless, as a result of their study abroad experiences in ELF communities, Turkish exchange students demonstrated a linear transition from lower self-efficacy to higher self-efficacy, which enabled them to feel more confident in using English for communicative purposes:

Participant 4: While interacting with the Spanish, I feel like a native speaker of English. Moreover, I do not feel hindered anymore. I can ask anything in English without any hesitation. (Journal 3)

Participant 1: Now, it is easy to express my ideas and opinions. (Journal 3)

While their increased self-efficacy led to more interactions with their European peers, the participants raised concerns about their interactions with the native speakers of English due to communication breakdowns:

Participant 4: I feel nervous while interacting with Americans and Canadians. Since English is their native tongue, I fear making mistakes. I do not have any problems while speaking in English with friends coming from different backgrounds like me, though. As I said, I am hindered in English just while communicating with the native speakers. (Journal 2)

As seen in the last excerpt, the participants gradually overcame their self-confidence problems in the interactions they engaged with their European contemporaries (i.e., ELF communication), but similar to Kalocsai's (2009) participants, they felt intimidated to interact with the native speakers of English (i.e., ESL communication). 
4.3.2. Discovering the role of learner autonomy in language learning

As mentioned earlier, at the beginning of their sojourns, the Turkish students felt insecure while interacting with their European and Canadian peers, which led to a search for ways to improve their English. During this exploration phase, they realized that learner autonomy played a paramount role in improving their language:

Participant 3: I still encounter some unknown vocabulary during my courses, so I think I should improve my vocabulary a little bit more. Time to time, doing something to improve my vocabulary motivates me. (Journal 3)

Having realized the vitality of being autonomous learners, the participants became more motivated to develop strategies to improve their English language to engage in interactions with the other people in the visited ELF communities:

Participant 4: I have a Canadian friend with whom I constantly try to speak in English and ask about my mistakes. He helps me a lot. I have respectively fewer pauses while speaking in English compared to my early days here. (Journal 2)

Participant 3 also underlined the role of social interactions in developing especially her vocabulary:

Participant 3: I think attending social activities and meeting new people play a significant role in my development. Practicing new vocabulary and structures, to which I am often exposed in daily interactions, and looking up their meanings in the dictionary and on the Internet are also useful. (Journal 2)

Hence, study abroad in ELF communities can be regarded as a way to encourage language learners to become more autonomous since their lived experiences abroad lead them to explore new opportunities to use the language both inside and outside the classroom (Amuzie \& Winke, 2009).

\subsubsection{Re-conceptualizing the fluency/accuracy distinction depending on the visited ELF community}

Using English for real-life purposes during their study abroad in ELF communities led Turkish students to realize the global role of English as a tool for communication:

Participant 3: It is great that students here can speak English with native-like fluency besides their native tongue [German]. (Journal 4)

Participant 4: I have been studying in Holland and so far I have not met a person who cannot speak English. Starting from teenagers to elderly, everybody speaks English fluently. (Journal 1)

Yet, the nature of the visited ELF community played a paramount role in shaping their beliefs about the role of English as an international language since some ELF communities widely used English (see the excerpts above), while some did not:

Participant 5: In the streets [of Poland], there is almost no one who can speak English. (Journal 1)

The extent to which English was used in the ELF community not only determined their communicative needs but also made an influence on their beliefs about the fluency vs. accuracy distinction:

Participant 4: Although our speech sounds absurd (due to lack of accuracy), we can understand each other easily. This

situation negatively affects our language development but there is nothing to do about this. (Journal 4)

As seen above, some diarists complained about the lack of accuracy in their ELF interactions and its harmful effects on their language development, while others mentioned how the grammar-based instruction in Turkey inhibited their communication in real-life settings:

Participant 2: The English that is taught in Turkish schools is not consistent with the one that we have to use to pursue our lives here. We are used to speaking English on the basis of grammatical structures in Turkey. However, a majority of people here speak English fluently without any grammar. (Journal 3)

Participant 3: I have been learning English since $4^{\text {th }}$ grade, and now I am realizing the importance of using the language for communication.

These excerpts confirm that English language teaching in Turkey relies on grammar-based instruction with emphasis on accuracy over fluency (Işı k, 2011). In that sense, depending on their local practices as well as the communicative needs in ELF communities, some participants showed changes in their beliefs by underlining the role of negotiation of meaning as an important skill for communication, while others indicated that lack of accuracy hindered their language development.

\section{Discussion}

The present study aimed to explore the relationship between language learners' beliefs and their study abroad experiences within ELF communities. According to the findings of the language learner belief questionnaire (LLBQ), there was no statistically significant change in Turkish exchange students' beliefs about English language learning across pre- and post-study abroad. Although previous studies in the literature found that language learner beliefs were either strengthened or weakened as a result of study abroad (e.g., Amuzie \& Winke, 2009; Lee, 2007; Tanaka \& Ellis, 2003), this study's participants beliefs remained almost the same after spending approximately five months abroad. 
This finding, which falls contradictory with the results in the existing literature, can be reasoned by means of two possible explanations; the limited breadth of exposure to English in the communities visited and the restricted length of time spent abroad. In similar studies supporting the effect of study abroad on learner beliefs (e.g., Amuzie \& Winke, 2009; Lee, 2007; Tanaka \& Ellis, 2003), students had studied in an English-speaking countries such as the U.S., resulting in full exposure to English in their social and academic lives. In the present study, the participants studied in different ELF communities, thus, perception of personal benefits from the experience depended on the degree to which the target language was used as a vehicle for communication in their environment. As demonstrated in the qualitative findings, the Turkish exchange students who studied in countries such as Austria and Holland had greater exposure due to the fact that the local people extensively used English for communication, while those who were in countries such as Poland and Slovenia could not benefit from the experience as the local people did not speak English that much. This finding corroborates Kalocsai's (2009) study, which suggested that ELF is not the only language that Erasmus exchange students use within an ELF community, but sometimes they have to socialize in the local community using the local language. Additionally, the participants of the current research studied abroad for a limited length of time, which was a semester. If these students had studied abroad for a longer period of time, there may have been more evident changes in their beliefs about English language learning. This result is also in line with the findings of Amuzie and Winke (2009), which pointed out that the students who spent more time abroad demonstrated more changes in their belief systems, emphasizing that length of exposure is a crucial factor in determining the extent of change in learner beliefs. Yet, as Bardovi-Harlig and Bastos (2011) indicate, length of stay is a complex variable that needs to be approached with caution as it "not only measures the duration of stay in the target environment, but also encompasses the variables that characterize the stay" (p. 376). In this study, the participants had different experiences with the English language depending on the nature of the visited ELF community. This finding confirms the idea that length of stay is a multifaceted variable composed of several social and individual factors that determine the level of both exposure to English and intensity of interaction.

Additionally, results from the in-depth analyses conducted on each statement from the LLBQ indicated that the Turkish exchange students felt more distressed for the mistakes they made while communicating with others in English in the course of their study abroad sojourns. This result is related to their confrontation with a) their European contemporaries and b) native speakers of English language. According to Turkish National Agency (2011), Turkish exchange students cannot be academically and socially efficient as much as their European contemporaries since the Turkish foreign language education, which revolves around teaching de-contextualized language with emphasis on grammar, has been far from satisfactory (Işı1k, 2011). Also, in ELF communities, ELF speakers were not the only people the Turkish students interacted with, but they also communicated with the native speakers of English. Since Turkish students consider native speakers the authorities and native-speaker English as the norm (Ortaçtepe, 2012), as their journals indicated, each failure the participants of this study experienced while communicating with the native speakers of English led to the feelings of uneasiness. These results contradict Jenkins, Cogo, and Dewey's (2011) description of ELF speakers as "not the 'failed native speakers' of EFL, but - more often - highly skilled communicators who make use of their multilingual resources in ways not available to monolingual NSEs [native speakers of English], and who are found to prioritize successful communication over narrow notions of correctness" (p. 284). This inconsistency, however, results from the fact that the English language education in Turkey, as in many other countries, still relies on the English as a foreign language (EFL) paradigm (Iş1k, 2011) for which achieving native-like production is the primary goal of the language learners (Jenkins et al., 2011; Seidlhofer, 2001). In that sense, even though some diarists felt more comfortable while using English as a lingua franca, interacting with native speakers of English or the other ELF speakers with higher levels of proficiency remained a challenge for others.

While the EFL paradigm in Turkey had shaped their experiences of using English in different European countries, their socialization experiences in ELF communities also reframed their understanding of English as a lingua franca in terms of the role of a) practice, b) grammar, and c) culture. The Turkish exchange students indicated that they started to appreciate the role of practice in improving their English, and became more motivated to create their own opportunities to recycle what they had previously learned to be able to successfully sustain interactions with their non-native and native-speaker contemporaries. Similar to previous research (e.g., Dörnyei \& Csizer, 2002; Dörnyei, Csizer, \& Nemeth, 2006; Kalocsai, 2009; Virkkula \& Nikula, 2010), the study abroad students in this study came to recognize that English has a strategic position around the globe as a lingua franca and believe that it will maintain this position in the future. Although the breadth of ELF usage altered depending on the visited ELF community (e.g., whether English is being commonly used as a lingua franca by the local people or not), a majority of the Turkish students acknowledged the role of English as a global medium of communication.

Moreover, the participants' ELF interactions in different ELF communities provided them with a new perspective toward the accuracy vs. fluency distinction. Toward the end of their stay in ELF communities, the participants of the current study started to believe that error-free grammar was not really necessary to communicate fluently with other people from both the local country and the other Erasmus communities. Even though they still considered the nativespeaker English the norm, they made adjustments in their language to negotiate meaning with others in ELF communities as suggested in the literature (Jenkins, 2006, 2007; Kalocsai, 2009). While this shift from focus on form to focus on meaning concurs with research that attempted to identify the language features that might be specific to ELF, ${ }^{4}$ it also

\footnotetext{
${ }^{4}$ See Jenkins et al. (2011) and Seidlhofer (2004) for reviews on this issue.
} 
underlines the distinction between ESL and ELF communication. In their study, Tanaka and Ellis (2003) found that students came to recognize the importance of accuracy in the use of English as a result of study abroad. Given that Tanaka and Ellis's (2003) study was conducted in an English-speaking country, the U.S., the findings of the present study indicate that learner beliefs are not only dynamic, but also influenced by the context itself as well as the particular learning experiences within the larger context (e.g., Amuzie \& Winke, 2009; Lee, 2007; Tanaka \& Ellis, 2003; Yang \& Kim, 2011).

As a result of their study abroad in ELF communities, Turkish exchange students began to believe that they can still have good mastery in English without knowing about the cultures of English-speaking countries such as the U.S., U.K., and Australia, suggesting that successful ELF communication is independent of the cultural knowledge of the native speakers. These results corroborate Baker's (2009) study, which highlighted that students need the ability to negotiate meaning and be creative in their use of English in ELF contexts without focusing on the knowledge of the target language culture. The changes in the role of grammar and the emphasis on intercultural communication in language learning not only indicate a shift toward the ELF paradigm, but also confirm that ELF users will be the "agents of language change” (Brutt-Griffler, 1998, p. 387). Going back to Firth's (1996) definition of ELF as a contact language, the Turkish exchange students' experiences in ELF communities can be identified as a process of (re)prioritization of English for communicative purposes rather than a system of nativespeaker norms.

The results also indicated that the participants' pre-beliefs, post-beliefs, and study abroad perceptions were strongly related with each other. This finding suggests that a) learners begin study abroad programs with previously developed beliefs, and these beliefs influence their perceptions of study abroad (Cotterall, 1999; Horwitz, 1988) and b) learners develop their own perceptions of study abroad, and these evolving perceptions affect their ultimate belief systems (Murphy-Lejeune, 2002; Tanaka \& Ellis, 2003; Yang \& Kim, 2011). The high mean scores obtained from the Turkish exchange students' pre-belief questionnaire in regard to learner autonomy and learning English confirm the literature suggesting that students start any language learning task with certain preconceived notions or beliefs (Amuzie \& Winke, 2009). In other words, the participants' prior belief systems, especially those concerning learner autonomy and learning English in general, may have influenced both their study abroad experiences and their decisions to study abroad. Furthermore, the high mean scores from students' post-belief questionnaires, especially in terms of learner autonomy and learning English point out that the participants' perceptions of study abroad may have shaped their prior belief systems. In that sense, the present study suggests a bi-directional relationship between language learners' beliefs and their study abroad experiences.

\section{Conclusion}

This exploratory study conducted with 53 Turkish exchange students from a state university in Turkey has reported on the relationship between study abroad students' experiences in ELF communities and their beliefs about English language learning. The results of the present study constitute an attempt to demonstrate the role of communicative contexts abroad on language learner beliefs. In that sense, this study, conducted in distinctive ELF communities, corroborates the findings of studies that have shown that learner beliefs are dynamic, and evolve around study abroad contexts (e.g., Kline, 1998; Levin, 2001; Mathews, 2001), implying that language learner beliefs are bi-directionally related to the perceptions of study abroad sojourns. In other words, beliefs about English language learning and perceptions of study abroad experiences in ELF communities strengthen or weaken simultaneously. However, the findings also suggest that observing any change in learner beliefs requires a longer period of time spent in ELF contexts.

This study also provides a strong ground for the assumption that language learner beliefs are not homogenous and stable, but contradictory from time to time (Tanaka \& Ellis, 2003). Although the participants of the present study reported a commitment toward native-speaker norms, they shifted their focus from accuracy to intelligibility, which helped them achieve their ultimate goal in ELF communities, successful interaction. Lastly, the findings of the current study illustrate that although English is the lingua franca of the millennium (e.g., Jenkins, 2006, 2007; Seidlhofer, 2005), the limited use of English in some ELF communities, as indicated in the participants' journals, suggests that it will take more time for English to be widely used as a shared language in some countries, specifically the ones in the eastern Europe. Yet, familiarizing language learners and teachers with the term ELF may be a good step to promote this process.

The findings of the present study should be treated with caution, as none of the participants had negative beliefs about the English language at the beginning of their study abroad sojourns. Four of the five diarists had positive beliefs, implying that since they were all volunteers as Erasmus students, they already had positive beliefs about English language learning. Further research can be conducted to compare the beliefs of those who do and who do not study abroad.

The results of this study also confirm that learner beliefs are dynamic and context specific (e.g., Amuzie \& Winke, 2009; Barcelos, 2003; Lee, 2007; Negueruela \& Azarola, 2011; Pajares, 1992; Tanaka \& Ellis, 2003; Yang \& Kim, 2011). Regarding the idiosyncratic features of ELF communities, the students in this study had different experiences in regard to the use of English as a lingua franca. More in-depth studies can be conducted by selecting two distinct ELF communities depending on the extent of English use to shed light on the context-dependent factors that enhance or hinder the use of ELF. Furthermore, studies can be carried out in a totally distinctive ELF community such as Malaysia, Indonesia, the Philippines, Algeria, China, and/or Japan to explore whether and in what ways different contexts impact language learner beliefs. 


\section{Appendix 1. Language learner belief questionnaire (LLBQ)}

\section{Self-Efficacy}

1. I believe I can eventually speak English very well.

2. I am afraid of making mistakes when speaking to other people.

3. I can easily express myself in English.

4. I don't feel comfortable when speaking English.

5. I am above the average in learning English.

\section{Learner Autonomy}

6. I would like to make an effort to speak English when I go abroad.

7. I should find my own opportunities to use English.

8. It is important to repeat and practice English.

9. I also should do something outside of the classroom to be successful in English.

Attitudes toward the Role of English in the World

10. English doesn't belong to one country.

11. English is a world language.

12. English doesn't belong to one culture.

13. English will still be important in the world in the future (upcoming years).

14. Mastering English is very helpful in understanding the foreigners and their cultures.

15. I can make friends from different countries by using English.

16. Most Turks need English to communicate with non-native speakers of English (such as Japanese, Polish, German and etc.).

17. It is necessary to know British or American culture to speak English well.

\section{Attitudes toward Learning English}

18. English is a difficult language to learn.

19. I will never study English after school (finishes).

20. I would like to speak English as my mother tongue.

21. I would like to work in a field which will give me the chance to use English.

22. I read English newspapers and magazines as much as possible.

23. I plan to learn English as much as possible.

24. Speaking English with a Turkish accent is bad.

25. I try a lot to learn English.

26. I watch English TV programs as much as possible.

27. I really enjoy learning English.

28. Learning English is a waste of time.

29. It is necessary to know British or American culture to speak English well.

\section{Appendix 2. Study abroad perception questionnaire (SAPQ)}

1. It was fun to study abroad.

2. It is beneficial to study abroad.

3. Attending a study abroad program helped me to get a more global perspective.

4. I developed my English communication skills thanks to studying abroad.

5. I thought studying abroad was boring.

6. Studying abroad will enable me to get a good job after graduation.

7. Studying abroad did not appeal to me.

8. I developed necessary skills to live in a foreign country while studying abroad.

9. I can describe my experiences of studying abroad as very amusing.

10. I am grateful to the university I study at for offering the opportunity to study abroad.

11. It is a waste of time to study abroad.

12. I developed my social relationships with foreigners during studying abroad.

13. Studying abroad helped me notice my strengths and weaknesses as a student.

14. I believe that studying abroad will help me be more successful at school.

15. Studying abroad was a nice experience.

\section{References}


Alexander, P. A., \& Dochy, F. (1995). Conceptions of knowledge and beliefs: a comparison across varying cultural and educational communities. American Educational Research Journal, 32, 413-442.

Allen, H., \& Herron, C. (2003). A mixed-methodology investigation of the linguistic and affective outcomes of summer study abroad. Foreign Language Annals, 36, 370-385.

Amuzie, G., \& Winke, P. (2009). Changes in language learning beliefs as a result of study abroad. System, 37, 366-379.

Baker, W. (2009). The cultures of English as a lingua franca. TESOL Quarterly, 43, 567-592.

Barcelos, A. M. F. (2003). Researching beliefs about SLA: a critical review. In P. Kalaja, \& A. M. F. Barcelos (Eds.), Beliefs about SLA: New research approaches (pp. 7-33). London: Kluwer Academic Publishers.

Bardovi-Harlig, K., \& Bastos, M. T. (2011). Proficiency, length of stay, and intensity of interaction, and the acquisition of conventional expressions in L2 pragmatics. Intercultural Pragmatics, 8(3), 347-384.

Barron, A. (2003). Acquisition in interlanguage pragmatics: Learning how to do things with words in a study abroad context. USA: John Benjamins.

Berns, M. (2009). English as a lingua franca and English in Europe. World Englishes, 28(2), 192-199.

Brutt-Griffler, J. (1998). Conceptual questions in English as a world language: taking up an issue. World Englishes, 17(3), $381-392$.

Carroll, J. (1967). Foreign language proficiency levels attained by language majors near graduation from college. Foreign Language Annals, 1, 131-151.

Cotterall, S. (1999). Key variables in language learning: what do learners believe about them? System, 27, $493-513$.

Deci, E. L., Eghrari, H., Patrick, B. C., \& Leone, D. (1994). Facilitating internalization: the self-determination theory perspective. Journal of Personality, 62, $119-142$.

DeKeyser, R. (1991). Foreign language development during a semester abroad. In B. F. Freed (Ed.), Foreign language acquisition research and the classroom (pp. 104-131). Lexington, DC: D.C. Heath \& Co.

Dewey, D. (2004). A comparison of reading development by learners of Japanese in intensive domestic immersion and study abroad contexts. Studies in Second Language Acquisition, 26, 303-327.

Dörnyei, Z., \& Csizer, K. (2002). Some dynamics of language attitudes and motivation: results of a longitudinal nationwide survey. Applied Linguistics, 23, $421-462$.

Dörnyei, Z., Csizer, K., \& Nemeth, N. (2006). Motivation, language attitudes and globalization: A Hungarian perspective. England: Multilingual Matters.

Elder, C., \& Davies, A. (2006). Assessing English as a lingua franca. Annual Review of Applied Linguistics, 26, $282-301$.

Eurostats News Release. (October 9, 2013). Two-thirds of working age adults in the EU28 in 2011 state they know a foreign language. Released date: 26 September 2013. Retrieved from http://epp.eurostat.ec.europa.eu/cache/ITY_PUBLIC/3-26092013-AP/EN/3-26092013-AP-EN.PDF.

Firth, A. (1996). The discursive accomplishment of normality: on 'lingua franca' English and conversation analysis. Journal of Pragmatics, 26, 237-259.

Freed, B. F. (1990). Language learning in a study abroad context: the effects of interactive and noninteractive out-of-class contact on grammatical achievement and oral proficiency. In Alatis (Ed.), Linguistics, language teaching, and language acquisition: The interdependence of theory, practice, and research (pp. 459-477). Washington, DC: Georgetown University Press.

Hashimoto, H. (1993). Language acquisition of an exchange student within the home stay environment. Journal of Asian Pacific Communication, 4, $209-224$.

Hatch, E., \& Lazaraton, A. (1991). The research manual: Design and statistics for applied linguistics. NY: Newbury House Publishers.

He, D., \& Li, D. S. (2009). Language attitudes and linguistic features in the "China English" debate. World Englishes, $28,70-89$.

Horwitz, E. K. (1985). Using student beliefs about language learning and teaching in the foreign language methods course. Foreign Language Annals, 18, $333-338$.

Horwitz, E. K. (1988). The beliefs about language learning of beginning university foreign language students. The Modern Language Journal, 72, $283-294$.

Horwitz, E. K. (1999). Cultural and situational influences on foreign language learners' beliefs about language learning: a review of BALLI studies. System, 27, $557-576$.

Howard, M. (2005). On the role of context in the development of learner language: insights from study abroad research. ITL Review of Applied Linguistics, 147, $1-20$.

Huck, S. W. (2004). Reading statistics and research (4th ed.). USA: Pearson.

Ișı, A. (2011). Language education and ELT materials in Turkey from the path dependence perspective. Hacettepe University Journal of Education, 40, $256-266$.

Jenkins, J. (2006). Points of view and blind spots: ELF and SLA. International Journal of Applied Linguistics, 16, $137-162$.

Jenkins, J. (2007). English as a lingua franca: Attitude and identity. Oxford: Oxford University Press.

Jenkins, J. (2009). English as a lingua franca: interpretations and attitudes. World Englishes, 28, $200-207$.

Jenkins, J., Cogo, A., \& Dewey, M. (2011). Review of developments in research into English as a lingua franca. Language Teaching, 44(3), 281-315.

Jones, G. C., \& Cunningham, G. B. (2008). The impact of sport management students' perceptions of study abroad programs on their intentions to study abroad. Sport Management Review, 11, 149-163.

Kalocsai, K. (2009). Erasmus exchange students: a behind-the-scenes view into an ELF community of practice. Journal of Applied Language Studies, 3, 25-49.

Kasapoğlu-Önder, R., \& Balcı, A. (2010). Erasmus öğrenci öğrenim hareketliliği programının 2007 yılı yararlanıcısı Türk ögrencileri üzerindeki etkileri (The effects of Erasmus student exchange program on Turkish students). Ankara Avrupa Çalımaları Dergisi (Ankara Review of European Studies), 9, 93-116.

Kinginger, C. (2008). Language learning in study abroad: case studies of Americans in France. The Modern Language Journal, 92, $1-131$.

Kinginger, C. (2009). Language learning and study abroad: A critical reading of research. UK: Palgrave Macmillan.

Kline, R. (1998). Literacy and language learning in a study abroad context. Frontiers: The Interdisciplinary Journal of Study Abroad, 4, $139-165$.

Kobayashi, Y. (2002). The role of gender in foreign language learning attitudes: Japanese female students' attitudes towards English learning. Gender E' Education, 14, 181-197.

Lee, E. (2007). An investigation of learner beliefs at two stages of study abroad (Doctoral Dissertation). Retrieved from Dissertations \& Theses. A\&I. AAT 1444278.

Lee, J. F. K. (2009). ESL student teachers' perceptions of a short-term overseas immersion programme. Teaching and Teacher Education, 25, 1095-1104.

Levin, D. M. (2001). Language learners' sociocultural interaction in a study abroad context. Unpublished Ph.D. Dissertation. Bloomington, IN: Indiana University.

Magnan, S. (1986). Assessing speaking proficiency in the undergraduate curriculum: data from French. Foreign Language Annals, $19,429-438$.

Mathews, S. A. (2001). Russian second language acquisition during study abroad: Gender differences in student behavior. Unpublished Ph.D. Dissertation. Pennsylvania: Bryn Mawr College.

Matsumura, S. (2001). Learning the rules for offering advice: a quantitative approach to second language socialization. Language Learning, 51, 635-679.

Mauranen, A., Perez-Llantada, C., \& Swales, J. M. (2010). Academic Englishes: a standardized knowledge? In Kirkpatrick (Ed.), The Routledge handbook of world Englishes (pp. 634-652) London: Routledge.

Murphy-Lejeune, E. (2002). Student mobility and narrative in Europe. London: Routledge.

Negueruela, E., \& Azarola, E. (2011). Beliefs as conceptualizing activity: a dialectical approach for the second language classroom. System, 39, 359-369.

Norton, B. (2000). Identity and language learning: Gender, ethnicity, and educational change. London: Pearson Education.

Ortaçtepe, D. (2012). The development of conceptual socialization in international students: A language socialization perspective on conceptual fluency and social identity. UK: Cambridge Scholarly Publishers.

Ortaçtepe, D. (2013). "This is called free falling theory not culture shock!": a narrative inquiry on second language socialization. Journal of Language, Identity and Education, 12, 215-229.

Pajares, M. (1992). Teachers' beliefs and educational research: cleaning up a messy construct. Review of Educational Research, 62(3), $307-332$.

Pan, L., \& Block, D. (2011). English as a “Global Language” in China: an investigation into learners' and teachers' language beliefs. System, 39, $391-402$.

Razali, N. M., \& Wah, Y. B. (2011). Power comparisons of Shapiro-Wilk, Kolmogorov-Smirnov, Lilliefors and Anderson-Darling tests. Journal of Statistical Modeling and Analytics, 2(1), 21-33. 
Ryan, R. M. (1982). Control and information in the intrapersonal sphere: an extension of cognitive evaluation theory. Journal of Personality and Social Psychology, 43, 450-461.

Sasaki, M. (2004). A multiple-data analysis of the 3.5-year development of EFL student writers. Language Learning, 54, 525-582.

Sasaki, M. (2007). Effects of study-abroad experiences on EFL writers: a multiple-data analysis. The Modern Language Journal, 91, 602-620.

Sasaki, M. (2011). Effects of varying lengths of study-abroad experiences on Japanese EFL students' L2 writing ability and motivation: a longitudinal study. TESOL Quarterly, 45(1), 81-105.

Sakui, K., \& Gaies, S. J. (1999). Investigating Japanese learners' beliefs about language learning. System, 2, 473-492.

Schumann, F., \& Schumann, J. (1977). Diary of a language learner: introspective study of SLA. In H. D. Brown, C. Yorio, \& R. Crymes (Eds.), TESOL '77 (pp. $241-$ 249). Washington, DC: TESOL.

Segalowitz, N., \& Freed, B. F. (2004). Context, contact and cognition in oral fluency acquisition: learning Spanish in at home and in study abroad contexts. Studies in Second Language Acquisition, 26, 173-199.

Seidlhofer, B. (2001). Closing a conceptual gap: the case for a description of English as a lingua franca. International Journal of Applied Linguistics, 11(2), $133-158$.

Seidlhofer, B. (2004). Research perspectives on teaching English as a lingua franca. Annual Review of Applied Linguistics, 24, 209-239.

Seidlhofer, B. (2005). English as a lingua franca. ELT Journal, 59, 339-341.

Serrano, R., Llanes, A., \& Tragant, E. (2011). Analyzing the effect of context of second language learning: domestic intensive and semi-intensive courses vs. study abroad in Europe. System, 39, 133-143.

Shardakova, M. (2005). Intercultural pragmatics in the speech of American L2 learners of Russian: apologies offered by Americans in Russian. Intercultural Pragmatics, 2, 423-454.

Strauss, A., \& Corbin, J. (1990). Basics of qualitative research: Grounded theory procedures and techniques. Newbury Park, CA: Sage.

Tanaka, K. (2007). Japanese students' contact with English outside the classroom during study abroad. New Zealand Studies in Applied Linguistics, $13,36-54$.

Tanaka, K., \& Ellis, R. (2003). Study-abroad, language proficiency, and learner beliefs about language learning. JALT Journal, $25,63-85$.

Thompson, B. (2008). Foundations of behavioral statistics: An insight-based approach. New York: Guilford.

Turkish National Agency [Türk Ulusal Ajansı]. (2011). Yayınlar ve istatikler. (Publications and statistics). Retrieved from http://www.ua.gov.tr/index.cfm? action=detay\&yayinid =45050908629B860D164FBBEA176AE5F658115\&CFID=345604\&CFTOKEN=70435676

Virkkula, T., \& Nikula, T. (2010). Identity construction in ELF contexts: a case study of Finnish engineering students working in Germany. International Journal of Applied Linguistics, 20, 251-273.

Wenden, A. L. (1998). Metacognitive knowledge and language learning. Applied Linguistics, 19, $515-537$.

Wenden, A. L. (1999). An introduction to metacognitive knowledge and beliefs in language learning beyond the basics. System, $27,435-441$.

Wood, D. (2007). Mastering the English formula: fluency development of Japanese learners in a study abroad context. JALT Journal, 29, 209-230.

Yang, J. S., \& Kim, T. Y. (2011). Sociocultural analysis of second language learner beliefs: a qualitative case study of two study-abroad ESL learners. System, 39 , $325-334$.

Zhang, X., \& Cui, G. (2010). Learning beliefs of distance foreign language learners in China: a survey study. System, 38, 30-40. 